Hugoye: Journal of Syriac Studies, Vol. 7, 107-110

(C) 2007 by Beth Mardutho: The Syriac Institute and Gorgias Press

\title{
BRIEF ARTICLE
}

\section{RECENT BOOKS ON SYRIAC TOPICS}

\section{PART 7}

\section{SEBASTIAN P. BROCK \\ UNIVERSITY OF OXFORD}

[1] The present listing continues on from previous listings in Hugoye (1998:1, 1999:1, 2000:1, 2001:1, 2002:1 and 2003:1). Reprints are not included (for a large selection of these, see www.gorgiaspress.com).

\section{1}

Iskandar, Amine Jules: La dimension syriaque dans l'art et l'architecture 2002 au Liban (Kaslik: Université Saint Esprit).

- Textes syriaques. Dien Miséricorde, Dien Amour (Patrimoine Syriaque: Colloque VIII; Antelias: CERO).

Anikuzhakattil, T.: Jesus Christ the Saviour. Soteriology according to East Syriac Tradition. A Biblico-theological Study of the East Syriac Soteriology in the Light of the Gospel according to Matthew and the Acts of Judas Thomas with special reference to the Mar Thoma Nazranai Traditions (Satna: Ephrem's Publications).

Coakley, J.F.: Robinson's Paradigms and Exercises in Syriac Grammar (5 $5^{\text {th }}$ edition; Oxford: University Press).

de Courtois, S.: Le génocide oublié: Chrétiens d'Orient, les derniers araméens (Collection l'Orient politique. Paris: Editions Ellipses). [English translation forthcoming]. 
Grillmeier, A. (ed. Hainthaler, T.): Jesus der Christus im Glauben der Kirche II.3. Die Kirchen von Jerusalem und Antiochien nach 451 bis 600 (Freiburg i B.: Herder). [Much of Syriac relevance].

Kiraz, G.A. (ed.): Hugoye: Journal of Syriac Studies, 5 (Piscataway, NJ: Beth Mardutho: The Syriac Institute). [Printed version].

Michaelsein, J.: Efraims Lovsang. Efraim Syrerens Hymner (Frederiksberg).

Odisho M. Gewargis Ashita: The Book of Ashitha. Historical, Cultural, Religious, Social Study [in Modern Syriac] (Baghdad: the Author).

Panicker, M.J.: The Person of Christ in the Writings of Juhanon Gregorius Abu'l Faraj commonly called Bar Ebraya (Studien zur orientalischen Kirchengeschichte, 4; Münster/Hamburg: LIT). [Not 2001, as previously given in Hugoye 5:1 (2002).]

Pinggéra, K.: All-Erlösung und All-Einheit. Studien zum 'Buch des beiligen Hierotheos' und seiner Rezeption in der syrisch-orthodoxen Theologie (Sprachen und Kulturen des christlichen Orients 10; Würzburg).

Roux, R.: L'Exégèse biblique dans les Homélies de Sévère d'Antioche (Studia Ephemeridis Augustinianum, Rome).

Shoemaker, S.J.: Ancient Traditions of the Virgin Mary's Dormition and Assumption (Oxford: University Press). [Much concerning Syriac texts].

Shleymon Isho' Khadbshaba (ed.): Khamis bar Qardahe: Memre wmušhata (Nuhadra, Iraq) [Nassibin@yahoo.de].

Yousif, E-I.: Les chroniqueurs syriaques (Paris: L'Harmattan).

2003

- Dien Miséricorde, Dien Amour. Actes du Colloque VIII. Patrimoine syriaque, I- II (Antelias: CERO).

Aprem, Mar: The Assyrian Church of the East in the Twentieth Century (Moran Etho 18; Kottayam: SEERI).

Baum, W.: Schirin: Christin-Königen-Liebesmythos (Klagenfurt: Kitab).

Baum, W. and Winkler, D.W.: The Church of the East. A Concise History (London: Routledge). [tr. from German original of 2000].

Bengtsson, P.A., Translation Techniques in Two Syro-Arabic Versions of Ruth (Studia Orientalia Lundensia, Nova Series 3; Lund/Stockholm: Almqvist \& Wicksell). 
Brock, S.P. (tr. K. Pinggéra): Die Weisheit Isaaks des Syrers. Eine Auswabl aus seinem Werk (Würzburg: Der christliche Osten).

Calduch-Benages, N., Ferrer, J., and Liesen, J.: La Sabiduría del Escriba: Wisdom of the Scribe. Diplomatic Edition of the Syriac Version of the Book of Ben Sira according to Codex Ambrosianus with Translations in Spanish and English (Biblioteca Madrásica 26; Estella, Navarra: Editorial Verbo Divino). [ISBN 848169-517-3]

Camplani, A.: Atanasio di Alessandria, Lettere Festali; Anonimo, Indice delle Lettere Festali. Introduzione, traduzione e note (Milan: Paoline).

Kaniyamparampil, E.: The Spirit of Life. A Study of the Holy Spirit in the Early Syriac Tradition (Oriental Institute of Religious Studies India, 268; Kottayam).

Klijn, A.F.J.: The Acts of Thomas (2nd edition; Suppl. to Novum Testamentum 108; Leiden: Brill).

Louf, A.: Isaac le Syrien. Oeuvres spirituelles, II. 41 Discours récemment découverts (Spiritualité Orientale 81; Bégrolles en Mauges: Abbaye de Bellefontaine).

Maas, M.: Exegesis and Empire in the Early Byzantine Mediterranean. Innillus Africanus and the Instituta Regularia Divinae Legis. With a contribution by E.G. Mathews (Studien und Texte zu Antike und Christentum, 19; Tübingen: Mohr Siebeck).

Nir, R.: The Destruction of Jerusalem and the Idea of Redemption in the Syriac Apocalypse of Baruch (SBL Early Judaism and its Literature, 20; Leiden: Brill).

Paul, K.P.: The Eucharist Service of the Syrian Orthodox Church: Meaning and Interpretation (Piscataway, NJ: Gorgias Press).

Perrin, N.: Thomas and Tatian. The Relationship between the Gospel of Thomas and the Diatessaron (Leiden: Brill).

PRO ORIENTE: Syriac Dialogue 5 (Vienna: Pro Oriente).

Ravasi, G., Ibrahim, G., Bettiolo, P., Lenzi, G., Vergani, E., Chialà, S., Nin, M., and Navoni, M. (ed. E. Vergani and S. Chialà): Le ricchezze spirituali delle Chiese Siri (Milan: Centro Ambrosiana).

Sauma, Assad: Gregory Bar-Hebraeus' Commentary on the Book of Kings from his Storehouse of Mysteries (Acta Universitatis Upsaliensis. Studia Semitica Upsaliensia 20; Uppsala). 
Teixidor, J.: Aristote en syriaque. Paul le Perse, logicien du VIe siècle (Paris: CNRS).

Tezel, A.: Comparative Etymological Studies in the Western Neo-Syriac (Turoyo) Dialect (Acta Universitatis Upsaliensis, Studia Semitica 18; Uppsala).

Thumpanirappel, G.: Christ in the East Syriac Tradition. A Study of the Christology of the Assyrian Church of the East and the Common Theological Declaration of 1994 (Satna: Ephrem's Publications).

Wagner, C.J.: Polyglotte Tobit-Synopse: Griechisch-Lateinisch-SyrischHebräisch-Aramäisch: mit einem Index zu den Tobit-Fragmente vom Toten Meer (Abhandlungen der Akademie der Wissenschaften, Göttingen, phil.-hist. Kl. III.258 = Mitteilungen des Septuaginta-Unternehmens, 28; Göttingen: Vandenhoeck \& Ruprecht).

Weltecke, D.: Die "Beschreibung der Zeiten” von Mor Michael dem Grossen (1126-1199): eine Studie zu ibrem historiographiegeschichtlichen Kontext (CSCO 594; Subsidia 110; Leuven: Peeters).

Winkler, D.W.: Ostsyrisches Christentum. Untersuchungen zu Christologie, Ekkelesiologie und zu den ökumenischen Beziehungen der Assyrischen Kirche des Ostens (Studien zur Orientalischen Kirchengeschichte 26; Münster: LIT).

Yousif, E.I.: La floraison des philosophes syriaques (Paris: L'Harmattan).

Zipor, M.: The Peshitta Version of Leviticus, with a Commentary [in Hebrew] (Jerusalem: Simor). 